\title{
PENINGKATAN KEMAMPUAN PEMAHAMAN MATEMATIKA SISWA SMP PGRI PAMANUKAN MELALUI MODEL PEMBELAJARAN KOOPERATIF TIPE STAD
}

\author{
Ika Sriyanti $^{1)}$, R.Poppy Yaniawati $^{2}$ \\ ${ }^{1,2}$ STKIP Subang \\ 1ikasriyanti99@gmail.com, ${ }^{2}$ pyaniwari@unpas.ac.id
}

\begin{abstract}
Abstrak
Penelitian ini bertujuan untuk meningkatkan kemampuan pemahaman matematika siswa melalui pembelajaran kooperatif tipe Student Teams Achievement Division (STAD) di Sekolah SMP PGRI Pamanukan. Pendekatan yang dilakukan dalam penelitian ini adalah kualitatif dengan Penelitian Tindakan Kelas (PTK) yang terdiri atas perencanaan, pelaksanaan, pengamatan (observasi) dan refleksi. Subyek penelitian siswa kelas VIII SMP PGRI Pamanukan dengan Materi Relasi dan fungsi. Teknik pengumpulan data menggunakan tes formatif setiap siklus dan observasi. Data yang diperoleh dianalisis dengan statistik deskriptif. Penelitian ini terdiri dari tiga siklus. Pada siklus pertama rerata nilai ulangan harian siswa masih tergolong rendah dan rerata nilai ulangan harian pada siklus kedua tergolong sedang sedangkan rerata nilai di siklus ketiga tergolong baik. Berdasarkan hasil observasi siswa pada siklus 1 masih kurang baik dengan presentase 44,3\% dan observasi guru 40,6 \%. Hasil observasi siklus kedua cukup baik dengan presentase siswa 54,3 \% dan guru 60,3\%. Hasil observasi siklus ketiga berkatagori baik dengan presentase siswa 68\% dan guru 89,5\%.Data yang berdasarkan statistik deskriptif dari siklus satu ke siklus dua ada peningkatan 0,18 yang berkriteria masih rendah, sedangkan dari siklus dua ke siklus tiga peningkatannya 0,34 yang berkriteria sedang. Berdasarkan Dari hasil penelitian tersebut maka dapat disimpulkan bahwa pembelajaran kooperatif tipe STAD mampu meningkatkan kemampuan pemahaman matematika hingga memenuhi Kriteria Ketuntasan Minimal (KKM).
\end{abstract}

Kata kunci: Pembelajaran kooperatif tipe STAD, Pemahaman Matematika, PTK

\section{PENDAHULUAN}

Pendidikan adalah usaha sadar dan terencana untuk mewujudkan suasana belajar dan proses pembelajaran agar peserta didik secara aktif mengembangkan potensi dirinya untuk memiliki kekuatan spiritual keagamaan, pengendalian diri, kepribadian, kecerdasan, akhlak mulia serta ketrampilan yang diperlukan dirinya, masyarakat, bangsa dan Negara. Materi matematika merupakan pelajaran yang sulit bagi sebagian besar siswa. Oleh karena itu berbagai cara dan model pembelajaran mengajar diperlukan untuk memperkecil kesulitan dalam pembelajaran matematika yang dapat meningkatkan pemahaman terhadap matematika.

Banyak kendala dalam mengajarkan matematika karena sebagian anak tidak suka dengan materi pelajaran matematika hal ini di tunjukan dari permasalahan berikut, yaitu: 1) Apabila guru sedang menjelaskan materi masih banyak siswa yang main-main dengan teman sebangkunya.2) Apabila guru bertanya kepada siswa tentang materi yang baru saja diajarkan, kebanyakan siswa diam saja dan tidak merespon pertanyaan dari guru.3) Sebagian besar siswa tidak berani bertanya kepada guru jika mereka belum memahami materi yang diajarkan. 4) masih ada siswa yang kaget jika guru meminta untuk mengerjakan soal di papan tulis . Dengan kurangnya Perhatian belajar akan berakibat pada hasil belajar yang kurang maksimal. Rendahnya hasil belajar matematika terlihat dari rendahnya nilai ulangan harian matematika di SMP PGRI selama tiga tahun terakhir seperti tampak pada tabel 1 .

Berdasarkan data-data di atas maka diperoleh fakta bahwa kemampuan pemahaman matematika siswa SMP PGRI Pamanukan masih kurang memuaskan. Sehingga upaya melalui model pembelajaran untuk meningkatkan kemampuan pemahaman matematika siswa tersebut 
belum tercapai. Menurut penelitian P. AtcA-mh, K.Profesionalitas (2011) Pemahaman adalah proses, cara, perbuatan mengerti atau mengetahui secara detail mengenai konsep tentang materi ajar yang diajarkan, yang tercermin meningkatnya hasil belajar siswa.

\section{Tabel 1}

Hasil Nilai Ulangan Harian

\begin{tabular}{cccc}
\hline Hasil/Tahun Pelajaran & $2012 / 2013$ & $2013 / 2014$ & $2014 / 2015$ \\
\hline Nilai rata-rata & 55,00 & 60,00 & 50,00 \\
Nilai Tertinggi & 80,00 & 85,00 & 75,00 \\
Nilai Terendah & 35,00 & 40,00 & 30,00 \\
\hline
\end{tabular}

(Sumber : Data ulangan harian SMP PGRI Pamanukan)

Berdasarkan latar belakang maka penelitian ini bertujuan untuk meningkatkan kemampuan pemahaman matematika siswa SMP PGRI Pamanukan melalui model pembelajaran kooperatif tipe STAD. W. Shanti, A. Abadi (2015) pembelajaran metode STAD adalah untuk memotivasi siswa agar saling membantu dalam memahami sebuah materi pelajaran dan saling membantu dalam menyelesaikan masalah. Agar mendapatkan penghargaan dari guru maka anggota tim harus memperoleh nilai yang tinggi dalam evaluasi yang diberikan. Oleh karena itu kerjasama tim dan saling memotivasi akan mengantarkan siswa pada kesuksesan.

Model pembelajaran kooperatif tipe STAD merupakan tim belajar beranggotakan empat orang yang merupakan campuran menurut tingkat kinerjanya, jenis kelamin dan suku. Guru menyajikan pelajaran kemudian siswa bekerja dalam tim untuk memastikan bahwa seluruh anggota tim telah menguasai pelajaran tersebut. kemudian seluruh siswa melakukan kuis tentang materi itu dengan catatan, saat kuis mereka tidak boleh saling membantu. Model Pembelajaran Koperatif tipe STAD merupakan pendekatan Cooperative Learning yang menekankan pada aktivitas dan interaksi diantara siswa untuk saling memotivasi dan saling membantu dalam menguasai materi pelajaran guna mencapai prestasi yang maksimal. Hubungan yang lebih akrab akan terjadi antara guru dengan siswa maupun antara siswa dengan siswa.

Berdasarkan uraian tersebut maka dilaksanakan penelitian tindakan kelas (PTK) dengan Meningkatkan kemampuan pemahaman matematika siswa SMP PGRI Pamanukan melalui model pembelajaran kooperatif tipe STAD (Student Team Achievement Divisions).

\section{METODE PENELITIAN}

Rancangan penelitian yang digunakan adalah penelitian kualitatif dengan penelitiaan tindakan kelas (PTK). Dalam hal ini peneliti bertindak sebagai guru, dengan dibantu oleh dua orang observer. Model rancangan ini mengacu pada rancangan model kemmis dan Taggart (1988) dengan tiga Siklus. Masing-masing siklus terdiri dari empat tahap yakni (1) penyusunan rencana tindakan, (2) Pelaksanaan tindakan (3) Pengamatan (Observasi) dan (4) Refleksi.

Pertama yang dilakukan peneliti yaitu observasi di sekolah dan mengindentifikasi masalah, melakukan perencanaan tindakan dengan metode PTK ( Penelitian Tindakan Kelas) melalui Siklus 1, siklus 2, Siklus 3. Menganalisis dan merefleksi tindakan siklus 1 dan siklus 2.

Setelah kegiatan dalam kelompok berjalan, kemudian dilakukan tes tertulis untuk mengetahui siswa dengan nilai tertinggi dan terendah. Nilai siswa juga dijadikan sebagai penentu kelompok terbaik dalam kelas tersebut. Kelompok terbaik akan mendapatkan suatu penghargaan dari guru. Hal ini dimaksudkan untuk memotivasi siswa agar belajar dengan lebih baik, Rancangan penyusunan Rencana Pelaksanaan Pembelajaran (RPP) yang digunakan sebagai panduan guru dalam melaksanakan pembelajaran di dalam kelas. Dalam penelitian ini RPP 
digunakan untuk memberikan perlakuan terhadap siswa yaitu dengan metode STAD. Analisis yang digunakan adalah analisis deskriptif yaitu sebuah analisis untuk menggambarkan data berdasar pada perhitungan mean, median, dan modus.

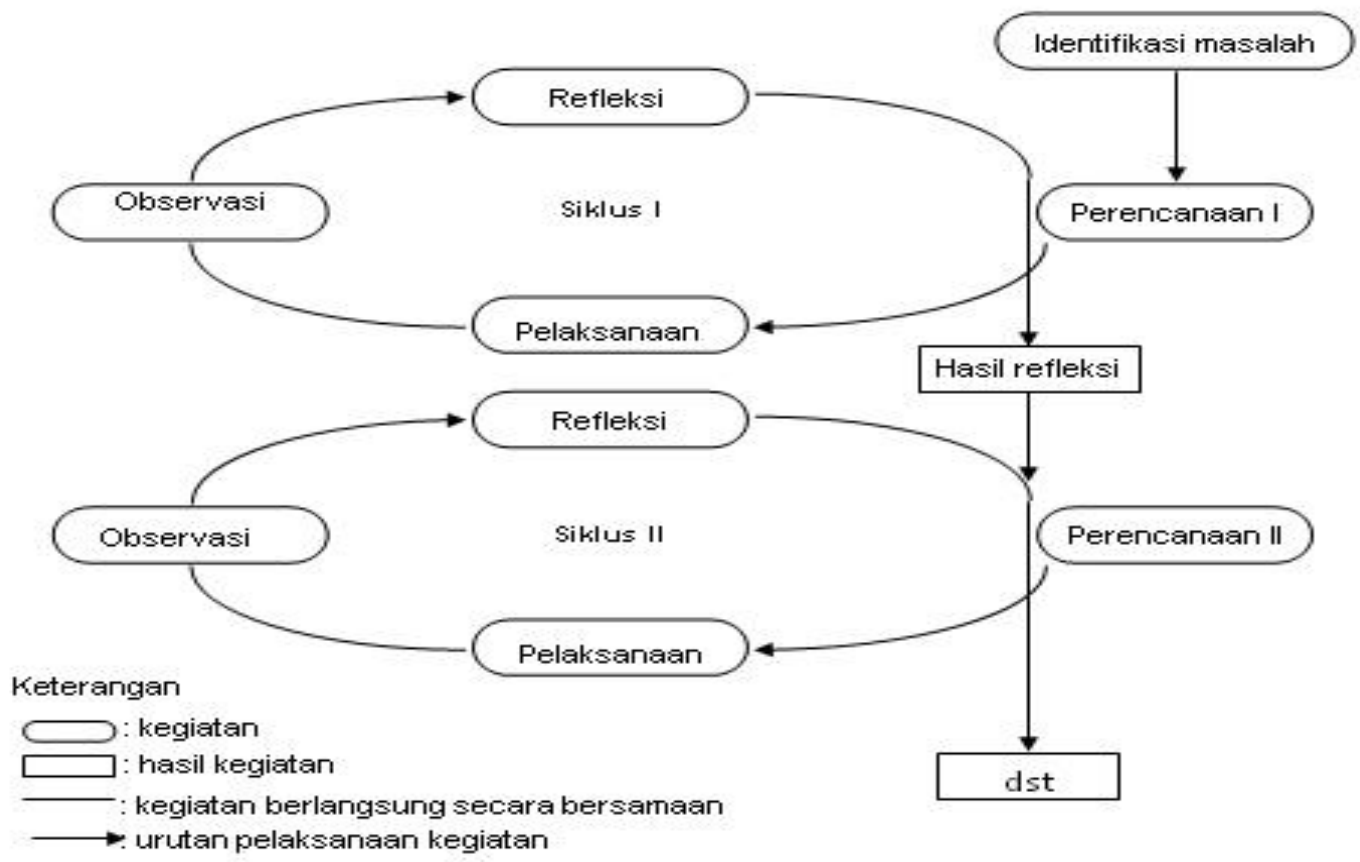

Gambar 1. Tahapan Kegiatan Penelitian Tindakan Kelas

\section{HASIL DAN PEMBAHASAN \\ SIKLUS 1}

Tahap-tahap Penelitian Tindakan Kelas di siklus I meliputi: langkah pertama Perencanaan Kegiatan siklus 1, guru menyiapkan Rencana Pembelajaran (RPP) dengan menggunakan model pembelajaran STAD. Siklus 1 terdiri dari 3 pertemuan termasuk tes siklus 1 yang dilaksanakan pada pertemuan ke-3. Siklus 1 dilakukan pada tanggal 26 Agustus Sampai dengan tanggal 3 Oktober 2015. Kompetensi dasar yang diberikan pada siklus 1 yaitu Kompetensi Dasar 1.3 Memahami relasi dan fungsi, materinya 1) Pengertian relasi dan fungsi ,2) Menyatakan relasi dan fungsi. Guru membuat Lembar Kerja Siswa, dan menyusun alat evaluasi pembelajaran. Dan guru membagi kelompok sesuai dengan kemampuan siswa.

Langkah kedua Pelaksanaan Tindakan siklus 1, guru membuka pelajaran serta menanyakan kesiapan siswa dalam mengikuti pelajaran. Kemudian guru menjelaskan tahapan proses belajar dengan menggunakan model pembelajaran kooperatif tipe STAD. Guru melaksanakan kegiatan pembelajaran tahap demi tahap sesuai dengan RPP. Pada saat siklus pertama, pelaksanaan belum sesuai dengan rencana, hal ini disebabkan oleh: sebagian siswa belum terbiasa dengan kondisi belajar kelompok, sebagian kelompok belum memahami lengkah-langkah pendekatan pembelajaran dengan menggunakan model pembelajaran kooperatif tipe STAD secara utuh dan menyeluruh,masih ada siswa yang tidak ikut mengerjakan LKS karena rasa perdulinya belum ada. Untuk mengatasi masalah diatas dilakukan upaya sebagai berikut: guru dengan intensif memberikan pengertian kepada siswa kondisi dalam kelompok, kerja sama kelompok, keikutsertaan siswa dalam kelompok, guru membantu kelompok yang belum memahami langkah- 
langkah pendekatan pembelajaran dengan menggunakan model-model pembelajaran kooperatif tipe STAD.

Langkah ketiga Observasi dan Evaluasi siswa pada siklus 1 menunjukan bahwa siswa masih belum aktif dalam mengikuti pembelajaran dengan menggunakan model pembelajaran kooperatif tipe STAD. Hal ini ditunjukan dari hasil observasi yang dapat dilihat pada lampiran masih kurang baik dengan presentase $44,3 \%$. Begitu juga observasi guru dalam pembelajaran siklus 1 masih tergolong kurang baik dengan presentase 40,6\%, karena belum terbiasa menggunakan model pembelajaran kooperatif tipe STAD. Berdasarkan hasil belajar matematika pada siklus 1, jika dilihat dari hasil tes menunjukan siswa belum memahami materi pembelajaran, hal ini terbukti dari hasil rata-rata nilai siklus 1 baru mencapai 6,02 dengan skor $<70$ nilai minimal 4,0 dan nilai maksimal 8,3 siswa yang tuntas mencapai 11 siswa sedangkan yang belum tuntas mencapai 19 siswa . Hal ini menunjukan Peningkatan siklus 1 masih Rendah.

Langkah keempat Refleksi siklus pertama proses dan hasil pembelajaran pada siklus 1 dapat dianalisis bahwa selama 3 kali pertemuan aktivitas siswa sangat bervariasi. Kekurangan pada siklus 1 bahwa aktivitas siswa belum optimal sesuai dengan yang diharapkan pada pembelajaran dengan menggunakan model pembelajaran kooperatif tipe STAD. Hal ini dapat dilihat pada aspek lembar observasi siswa masih kurang. Guru dalam mengelola pembelajaran masih tergolong kurang baik. Sedangkan pada hasil belajar siswa secara klasikal rata-rata nilai tes silkus 1=6,02 masih dibawah nilai Kriteria ketuntasan Siswa $(\mathrm{KKM})=70$.Adapun keberhasilan dan kegagalan yang terjadi pada siklus 1 adalah sebagai berikut : 1) guru belum terbiasa menciptakan suasana pembelajaran yang mengarah kepada pendekatan pembelajaran kooperatif tipe STAD. Hal ini diperoleh dari hasil observasi terhadap ketepatan prosedur pelaksanaan tindakan yang dilakukan guru atau peneliti dalam proses belajar mengajar kurang baik. 2) sebagaian siswa belum terbiasa dengan kondisi belajar dengan mengunakan pendekatan pembelajaran dengan menggunakan pembelajaran kooperatif tipe STAD. Mereka belum merasa senang dan antusias dalam belajar. 3) masih ada kelompok yang belum biasa menyelesaikan tugas dengan waktu yang ditentukan. Hal ini karena anggota kelompok tersebut kurang serius dalam belajar. 4) masih ada kelompok yang kurang mampu dalam mempresentasikan hasil diskusi kelompoknya.

\section{SIKLUS 2}

Tahap Siklus 2 meliputi langkah pertama perencanaan kegiatan siklus 2 berdasarkan hasil refleksi siklus pertama. Siklus 2 dilakukan pada tanggal 6 Oktober sampai dengan 7 Nopember 2015. Kompetensi dasar yang diberikan pada siklus 2 yaitu Menentukan nilai fungsi dengan materi 1) membuat rumus fungsi, 2) menentukan nilai fungsi, 3) Menentukan nilai fungsi dalam kehidupan sehari hari. Siklus 2 terdiri dari 3 pertemuan dan pertemuan ke tiga dilaksanakan tes siklus 2.

Langkah kedua Pelaksanaan Tindakan guru membuka serta menanyakan kesiapan siswa dalam mengikuti pelajaran. Guru melaksanakan kegiatan pembelajaran tahap demi tahap sesuai dengan RPP. Suasana pembelajaran sudah mengarah pada pembelajaran kooperatif tipe STAD. Tugas yang diberikan guru kepada kelompok dengan menggunakan Lembar Kerja Siswa (LKS) mampu dikerjakan dengan baik. Siswa dalam satu kelompok menunjukan saling membantu untuk menguasai materi pembelajaran yang telah diberikan melalui tanya jawab atau diskusi antara sesama anggota kelompok. Sebagian siswa sudah terlihat akan minatnya dalam belajar matematika dan merasa termotivasi untuk bertanya dan menanggapi suatu presentasi dari kelompok lain.

Langkah ketiga observasi dan evaluasi kegiatan guru dalam pembelajaran siklus 2 sebagai besar aspek berkatagori cukup baik dengan presentase 60,3\%, karena mulai terbiasa menggunakan 
model pembelajaran kooperatif tipe STAD. Begitu pun hasil observasi siswa pada siklus 2 menunjukan bahwa siswa mulai aktif dalam mengikuti pembelajaran dengan menggunakan model pembelajaran kooperatif tipe STAD. Hal ini di tunjukan dari hasil observasi siswa cukup baik dengan presentase 54,3\%. menunjukan siwa masih belum memahami materi pembelajaran walaupun ada peningkatan, hal ini terbukti dari hasil rata-rata nilai Quis 2 baru mencapai 6,81 dengan skor < 70 nilai minimal 2,5 dan nilai maksimal 8,5 siswa yang tuntas mencapai 16 siswa sedangkan yang belum tuntas mencapai 14 siswa lebih baik di bandingkan dengan siklus 1 .

Langkah keempat Refleksi, proses pada hasil pembelajaran pada siklus 2 dapat dianalisis bahwa aktivitas siswa sangat bervariasi. Kekurangan pada siklus 2 bahwa aktivitas siswa belum optimal sesuai yang diharapkan pada pembelajaran dengan menggunakan model pembelajaran kooperatif tipe STAD, namun lebih baik dari silkus 1. Hal ini bisa dilihat dari aspek-aspek lembar aktivitas siswa banyak yang tergolong kategori cukup baik, artinya pada siklus 2 hasil belajar siswa meningkat dengan menggunakan model pembelajaran kooperatif tipe STAD, dibandingkan dengan siklus 1 .

\section{SIKLUS 3}

Tahap Siklus 3 dilakukan pada tanggal 10 Nopember sampai tanggal 30 Nopember 2015. Kompetensi dasar yang diberikan pada siklus 3 yaitu Kompetensi dasar 1.5 membuat Sketsa grafik fungsi aljabar sederhana pada sistem koordinat cartesius, dengan materi menggambarkan grafik fungsi yang berkaitan dengan pemecahan masalah dalam kehidupan sehari-hari. Siklus 3 terdiri dari 2 petemuan dan diakhir pertemuan ketiga dilaksanakan tes Quis siklus 3

Langkah pelaksanaan tindakan Guru membuka serta menanyakan kesiapan siswa dalam mengikuti pelajaran. Guru melaksanakan kegiatan pembelajaran tahap demi tahap sesuai dengan RPP. Untuk memperoleh hasil yang lebih maksimal lagi dari model pembelajaran kooperatif tipe STAD, maka dilakukan usaha perbaikan pada siklus 3 sebagai berikut: 1) Guru akan melakukan pengaturan kelas, terutama bagi siswa-siswa yang melakukan aktifitas diluar pelajaran. Mengingatkan bahwa kegiatan diluar pembelajaran seperti bercanda, berbicara dengan teman saat pembelajaran berlangsung dan sebagiannya sangatlah tidak penting dan membuang-buang waktu. 2) Menjelaskan bahwa guru akan memberikan hadiah (reward) kepada dua kelompok siswa yang berprestasi, dan akan memberikan hukuman (Punishment) bagi siswa yang melakukan kesalahan.

Langkah Observasi dan evaluasi hasil observasi aktivitas guru dalam pembelajaran siklus 3 sebagai besar aspek berkatagori baik dengan presentase 89,5\%, karena mulai terbiasa menggunakan model pembelajaran kooperatif tipe STAD. Begitu pun observasi aktivitas siswa pada siklus 3 menunjukan bahwa siswa cukup aktif dalam mengikuti pembelajaran dengan menggunakan model pembelajaran kooperatif tipe STAD. Hal ini di tunjukan dari hasil observasi siswa cukup baik dengan presentase $68 \%$. Berdasarkan hasil belajar pada siklus 3, nampak bahwa hasil belajar siklus 3, jika dilihat dari hasil tes menunjukan siswa memahami materi pembelajaran dengan adanya peningkatan hasil belajar, hal ini terbukti dari hasil rata-rata nilai tes siklus 3 mencapai 8,03 dengan skor $\geq 70$ dengan maksimum 9,5 dan minimum 6,0 dan dikatakan tuntas walaupun masih ada 3 siswa lagi yg belum mencapai KKM. Dari siklus ke 3 sudah ada peningkatan dibandingkan siklus 1 dan 2. Berdasarkan hasil rata-rata nilai pemahaman matematika siklus 3 lebih tinggi dibandingkan dengan rata rata siklus 2. Demikian juga banyaknya siswa yang tuntas pada siklus 3 lebih banyak dibandingkan dengan siklus 2.

Langkah Refleksi pada siklus 3 menunjukan bahwa aktivitas siswa optimal sesuai yang diharapkan pada pembelajaran dengan menggunakan model pembelajaran kooperatif tipe STAD. Hal ini meningkat dari siklus 1 dan siklus 2, bisa dilihat dari aspek-aspek lembar aktivitas siswa 
banyak yang pada kategori cukup baik. Artinya pada siklus 3 hasil belajar siswa telah sesuai dengan pembelajaran dengan menggunakan model pembelajaran kooperatif tipe STAD. Pada lemabar observasi aktivitas guru,dalam rangka mengolah pembelajaran tergolong baik. Sedangkan pada nilai hasil belajar diperoleh ketuntasan klasikal diatas standar ketuntasan. Jadi hasil belajar siswa pada siklus 3 dikatakan sudah tuntas. Artinya baik guru maupun siswa sudah mulai memahami makna pembelajaran dengan menggunakan model pembelajaran kooperatif tipe STAD. Dari hasil rata-rata belajar siswa mulai siklus 1, Siklus 2 dan Siklus 3 lebih baik dari data rata rata awal tahun ajaran 2014/2015 sebelum menggunakan pembelajaran kooperatif tipe STAD. Terlihat dari Tabel 2 sebagai berikut:

Tabel 2

Rata-rata Hasil Tes Per Siklus

\begin{tabular}{cccc}
\hline Sumber Statistik & Siklus 1 & Siklus 2 & Siklus 3 \\
\hline N & 30 & 30 & 30 \\
X & 6,02 & 6,81 & 8,03 \\
Min & 4,0 & 2,5 & 6,0 \\
Max & 8,3 & 8,5 & 9,5 \\
\hline
\end{tabular}

Sumber: data hasil tes formatif per siklus

Tabel 3

Peningkatan dari Siklus 1 ke 2

\begin{tabular}{lcccc}
\hline & Siklus 1 & Siklus 2 & Peningkatan & Kriteria \\
\hline Rata-rata & 60,27 & 68,10 & & \\
Stand. dev & 14,64 & 13,96 & & \\
Subyek tuntas & 11 & 16 & 0,18 & Rendah \\
Subyek yg tdk tuntas & 19 & 14 & & \\
\hline Catatan: Nilai ideal 100 dan KKM 70 & & &
\end{tabular}

Tabel 4

Peningkatan dari Siklus 2 ke 3

\begin{tabular}{lcccc}
\hline & Siklus 2 & Siklus 3 & Peningkatan & Kriteria \\
\hline Rata-rata & 68,10 & 80,33 & & \\
Stand. dev & 13,96 & 9,55 & & \\
Subyek tuntas & 16 & 27 & 0,34 & Sedang \\
Subyek yg tdk tuntas & 14 & 27 & & \\
\hline Catatan: Nilai ideal 100 dan KKM 70 & & &
\end{tabular}

Pernyataan ini bisa dibuktikan dari hasil tes pemahaman matematika pada kelas eksperimen yang menggunakan pembelajaran kooperatif tipe STAD. B. Ilmu (2017) menyatakan bahwa Pembelajaran matematika yang diharapkan muncul adalah kemampuan memahami konsep matematika itu sendiri. Siswa yang memiliki pemahaman konsep yang bagus akan mengetahui lebih dalam tentang ide-ide matematika yang masih terselubung. Pengetahuan yang dipelajari dengan pemahaman akan memberikan dasar dalam pembentukan pengetahuan baru sehingga dapat digunakan dalam memecahkan masalah-masalah baru, setelah terbentuknya pemahaman dari sebuah konsep, siswa dapat memberikan pendapat, menjelaskan suatu konsep.

P. Hasil, B. Ips (2012) proses belajar mengajar berjalan seperti yang diharapkan, serta respon siswa sangat baik terhadap pembelajaran dan siswa sangat senang belajar, itu dilihat dari hasil yang didapatkan pada siklus I, 2 dan3 . Hal ini disebabkan pembelajaran langsung melibatkan siswa, guru hanya menjadi fasilitator saja, sehingga apa yang ditemukan siswa tidak mudah dilupakan . Terbukti pada hasil belajar pemahaman matematika tiap siklus mengalami kenaikan 
untuk rata-rata ketuntasan materi Relasi dan Fungsi. Ini dapat dilihat dari banyaknya siswa yang memperoleh nilai di atas KKM, artinya setiap siklus siswa yang tuntas setiap siklusnya semakin bertambah banyak.

Beberapa pengetahuan yang diperoleh peneliti dari penelitian P. Hasil, B. Ips (2012) terdiri atas: (1) banyaknya siklus yang digunakan dalam pelaksanaan Penelitian Tindakan Kelas menyesuaikan dengan hasil yang diperoleh, selama belum dapat mendapatkan hasil yang diharapkan maka siklus dapat ditambah, (2) rotasi kelompok dalam pembelajaran kooperatif tipe STAD dilakukan setelah siswa mencapai titik jenuh yaitu berlangsung selama tiga hingga lima kali pertemuan sehingga dapat diperoleh hasil yang lebih memuaskan, (3) semua tahapan dalam pembelajaran kooperatif tipe STAD harus dilaksanakan dengan disiplin, sehingga bisa dibuktikan kebenaran teorinya, dan (4) pembelajaran kooperatif tipe STAD mampu meningkatkan hasil belajar siswa. Pembelajaran kooperatif dengan menggunakan model kooperatif tipe STAD memungkinkan siswa untuk bekerjasama dalam kelompoknya. Dan memungkinkan siswa untuk belajar matematika secara bermakna artinya belajar matematika dengan masalah yang ada pada kehidupan sehari-hari.

Berdasarkan hasil dan pembahasan di atas, dapat dikatakan bahwa indikator keberhasilan tindakan dan aktivitas guru dan siswa telah tercapai dan mengalami peningkatan. Peningkatan tersebut tercapai karena dalam pembelajaran diterapkan model pembelajaran kooperatif tipe $S T A D$. Jadi, dapat disimpulkan bahwa model pembelajaran kooperatif tipe STAD dapat meningkatkan kemampuan pemahaman matematika pada siswa SMP PGRI Pamanukan.

\section{KESIMPULAN DAN SARAN}

Berdasarkan data dan pembahasan yang diperoleh dari siklus 1,2,3 maka dapat disimpulkan bahwa berdasarkan siklus 1, siklus 2, siklus 3 pembelajaran kooperatif tipe STAD mampu meningkatkan pemahaman matematika siswa SMP PGRI Pamanukan.

Berdasarkan kesimpulan diatas berikut ada beberapa saran untuk peningkatan motivasi, kemandirian dan hasil belajar siswa menggunakan pembelajaran kooperatif tipe STAD antara lain:

1. Berbagai upaya untuk menjaga kualitas hasil penelitian telah penulis upayakan, tetapi karena waktu, tenaga dan kemampuan maka hal tersebut menyebebkan penulis ini banyak kelemahannya.

2. Berdasarkan temuan penelitian yang menunjukan siswa senang dan tertarik terhadap pembelajaran kooperatif tipe STAD ini dapat digunakan dalam proses pembelajaran matematika untuk menciptakan suasana belajar yang menyenangkan dan memudahkan siswa dalam memahami materi yang diberikan.

\section{REFERENSI}

A-match, P. P. M., \& Profesionalitas, K. K. (2011). Model Pembelajaran Aktif dengan Menggunakan Metode, 2(1), 143-154.

Alkhairaat, M., \& Palu, P. (2016). Penerapan Model Pembelajaran Kooperatif Tipe STAD Penerapan Himpunan di Kelas VII.

Belajar, H. (2016). Peningkatan Hasil Belajar Siswa Pada Materi dan Persen dengan Metode Discovery, 3(1), 75-80.

Firmansyah. (2013). No Title. Peningkatan Kemampuan Pemahaman Matematika Melalui Metode Pembelajaran Kooperatif Tipe STAD (Tesis).

Hasil, P., \& Ips, B. (2012). Peningkatan Hasil Belajar IPS, 4(September), 424-431.

Ilmu, B. (2017). 213 Universitas Buana Perjuangan Karawang, 1(2), 213-229. 
Kurt, L. (1935). No Title. A. Dynamic Theory of Personality:selected Paper. New York : Mc GrawHill.

Indrawan, R \& Yaniawati (2015). Metode Penelitian. PT Refika paper.New york : Mc Graw-Hill

Rusefendi, E.T. (2015). Pengantar Kepada Membantu Guru Mengembangkan Kompetensinya Dalam Pengajaran Matematika Untuk Meningkatkan CBSA. Bandung, Tarsito.

Shanti, W. N., \& Abadi, A. M. (2015). Jurnal Riset Pendidikan Matematika. Riset Pendidikan Matematika, 2(November), 162-174. https://doi.org/10.21831/jrpm.v2i2.7348 